\title{
THE EFFECT OF D,L- $\beta$-AMINOBUTYRIC ACID ON THE GROWTH AND DEVELOPMENT OF FUSARIUM OXYSPORUM F. SP. TULIPAE (APT.)
}

\author{
Anna Jarecka, Alicja Saniewska \\ Research Institute of Pomology and Floriculture, \\ Pomologiczna 18, 96100 Skierniewice, Poland, e mail ajarecka@insad.pl
}

Received: 24.04.2007

\section{S u m m a r y}

The effect of $\mathrm{D}, \mathrm{L} \beta$ aminobutyric acid (BABA) on the growth and development of the root system and the development of fusariosis on tulip bulbs cv. Apeldoorn infected by Fusarium oxysporum f. sp. tulipae (F.ox.t. 218) was studied. The length and fresh weight of roots, the development of fusariosis on bulbs and the linear growth of mycelium of F.ox.t. 218 on PDA medium were measured. Preventively used BABA at a concentration of 100,250 and $300 \mu \mathrm{g} \cdot \mathrm{cm}^{3}$ for soaking uncooled and cooled tulip bulbs greatly inhibited the development of fusariosis on the root system; the length and fresh weight of roots were similar to those of the bulbs not inoculated with F.ox.t. 218. At a concentration of $100 \mu \mathrm{g} \cdot \mathrm{cm}^{3}$, BABA used for soaking bulbs limited the develop ment of fusariosis on scales in about $50 \%$ and the concentration of $200 \mu \mathrm{g}^{\cdot} \mathrm{cm}^{3}$ totally inhibited the disease symptoms induced by F.ox.t. 218. At a concentration of $100 \quad 1000 \mu \mathrm{g} \cdot \mathrm{cm}^{3}$, BABA did not inhibit the mycelium growth of F.ox.t. 17 and F.xo.t. 218 on PDA medium. This study suggests that BABA protects tulip roots and bulb scales against $F$. oxysporum $\mathrm{f}$. sp. tulipae by indu cing resistance in these organs and has no direct influence on the pathogen.

Key words: D,L $\beta$ aminobutyric acid, resistance, tulip bulbs, $F u$ sarium oxysporum $\mathrm{f}$. sp. tulipae

\section{INTRODUCTION}

$\mathrm{D}, \mathrm{L}-\beta$-aminobutyric acid (BABA) induces local and systemic resistance against different pathogens in many plant species. Changes occurring in plants under the influence of BABA are associated with resistance to pathogens, inter alia, with the accumulation of phenolic compounds, phytoalexin, salicylic acid, callose, hydrogen hydroxide, proteins associated with pathogenesis, lignin (Co h e n, 2002; J a k a b et al. 2001; Chams a i et al. 2004). BABA strongly reduced infection caused by downy mildew (Plasmopara viticola) in grapevine, in $57 \%$ on cv. Chardonnay and in $98 \%$ on $\mathrm{cv}$. Cabarnet Sauvignon (Reuveni et al. 2001).
The aim of the study was to determine the effect of BABA on the growth and development of the root system and the development of fusariosis on tulip bulbs infected by Fusarium oxysporum f sp. tulipae (F.ox.t.).

\section{MATERIAL AND METHODS}

The study was conducted in the years 2004-2005 at the Research Institute of Pomology and Floriculture in Skierniewice. In in vivo experiments, 'Apeldoorn' tulip bulbs and one isolate of Fusarium oxysporum $\mathrm{f}$. sp. tulipae (Apt.) (F.ox.t. 218), strongly infecting tulip bulbs, were used. In in vitro experiments two isolates of the pathogen, F.ox.t. 17 and F.ox.t. 218 were used. D,L- $\beta$-aminobutyric acid was obtained from the company Sigma-Aldrich.

The effect of BABA on the growth and development of the root system and the development of fusariosis on tulip bulbs.

Experiment 1. Tulip bulbs at the flower bud stage, uncooled, after the removal of the outer scale, were surface disinfected in $50 \%$ ethanol for $5 \mathrm{~min}$., and then they were rinsed 3 times in distilled and sterilised water. The basal plates of the tulip bulbs, together with newly-initiated roots, were soaked in water for 3 days, and next the partially developed root system (roots about $15 \mathrm{~mm}$ long) was treated in BABA at concentrations of 100 and $250 \mu \mathrm{g} \cdot \mathrm{cm}^{-3}$ for 20 hours. Before being planted to pots in sterile sand, a portion of the bulbs (roots and the basal plate area) was immersed in a solution of spores of F.ox. $t$. 218 isolate with a density of $1.2 \times 10^{6} \mathrm{spores} / \mathrm{cm}^{3}$ of the inoculum. Bulbs soaked in water, inoculated with the spore suspension and uninoculated, were the control. After 32 days from planting the bulbs, observations of the root system development and the healthiness of the bulbs were made.

Experiment 2. Tulip bulbs, surface disinfected and cooled at $5^{\circ} \mathrm{C}$ (without rooting), were planted in 
pots in sterile sand, and then after 4 days from planting they were preventively watered with BABA solution at a concentration of $300 \mu \mathrm{g}^{\cdot \mathrm{cm}^{-3}}\left(25 \mathrm{~cm}^{3} /\right.$ pot). The control plants were watered with distilled water. After 7 days from planting the bulbs, $12 \mathrm{~cm}^{3}$ of the suspension of spores of F.ox.t. 218 with a density of $1.2 \times 10^{6}$ spores $/ \mathrm{cm}^{3}$ of the inoculum was introduced into 4 holes in the pots in the root system area. The plants were watered for the second time with BABA solution (applying the same concentration and quantity of the solution as in the first watering) after 7 days from the inoculation with the pathogen spores. Bulbs inoculated and uninoculated with spores of F.ox.t. 218 were the control. After 29 days from planting the bulbs, the healthiness of the bulbs and the root system development were assessed.

Experiment 3. Daughter bulbs obtained from tulips grown in greenhouse conditions, after the removal of the first outer scale, were cut at the basal plate with a cork borer to a depth of 1-2 $\mathrm{mm}$ and at a diameter of $3 \mathrm{~mm}$. After cutting the scale, the bulbs were soaked for 12 hours in BABA solutions at concentrations of 100 and $200 \mu \mathrm{g} \cdot \mathrm{cm}^{-3}$. Thereafter, $20 \mu \mathrm{l}$ of the suspension of spores of F.ox.t. 218 with a density of $1.2 \times 10^{6}$ spores/ $\mathrm{cm}^{3}$ of the inoculum was put in the place of the bulb scale damage. Bulbs soaked for 12 hours in distilled water and inoculated with the suspension of the pathogen spores were the control. The inoculated bulbs were placed in trays on damp absorbent paper lined with aluminium foil. The trays with the bulbs were put into film bags in order to increase humidity. After 8 days of incubation of the bulbs at a temperature of $25^{\circ} \mathrm{C}$, the length of infection spots was measured.

The comparative fungicide was Sportak Alpha 380 EC $\left(300 \mathrm{~g}\right.$ prochloraz $+80 \mathrm{~g}$ carbendazim $\left./ \mathrm{dm}^{3}\right)$. In each combination, 10 bulbs were tested. The experiments were carried out in two series on the bulbs obtained in the study years.

The effect of BABA on the growth of Fusarium oxysporum f. sp. tulipae in vitro. BABA was added in such quantities that the concentrations were, respectively, 100, 250, 500 and $1000 \mu \mathrm{g}^{\cdot} \mathrm{cm}^{-3}$, to autoclaved potato dextrose agar medium (PDA-Merck), after sterilising and cooling to $45^{\circ} \mathrm{C}$. The prepared solutions were poured onto $90 \mathrm{~mm}$ Petri dishes. Medium without BABA addition was the control. $5 \mathrm{~mm}$ disks of PDA medium overgrown with a 7-day culture of two isolates of Fusarium oxysporum f. sp. tulipae (F.ox.t. 17 and F.ox.t. 218) were transferred onto solidified medium in the middle of the dishes. After 2, 4 and 6 days of incubation at a temperature of $25^{\circ} \mathrm{C}$ in dark, the diameter of the mycelium colony was measured in two perpendicular directions. For each BABA concentration, the linear growth of the mycelium of the tested isolates was analysed on 5 Petri dishes in two series at a weekly interval.

The results of the experiments were processed statistically, using the variance analysis. t-Duncan multiple range test was used for assessment of differences between the means, adopting the significance level $\alpha=0.05 \%$.

\section{RESULTS AND DISCUSSION}

Both the length of the roots and fresh weight in the bulbs inoculated with Fusarium oxysporum f. sp. tulipae (F.ox.t. 218) were strongly reduced compared to the control uninfected bulbs (Tab. 1,2).

Preventively applied D,L- $\beta$-aminobutyric acid (BABA) at a concentration of 100 and $250 \mu \mathrm{g} \cdot \mathrm{cm}^{-3}$ for soaking the basal plate of the tulip bulbs with newly-initiated roots (uncooled bulbs), as well as BABA applied at a concentration of $300 \mu \mathrm{g}^{\cdot} \mathrm{cm}^{-3}$ for watering cooled bulbs in the area of growing roots, favourably affected the development of the root system of the bulbs inoculated with spores of Fusarium oxysporum f. sp. tulipae (Tab. 1, 2); the development of the root system was fo-

Table 1

The effect of $\mathrm{D}, \mathrm{L} \beta$ aminobutyric acid (BABA) on the growth of the root system in uncooled tulip bulbs inoculated with spores of Fusarium oxysporum f. sp. tulipae (F.ox.t. 218); observation 32 days after inoculation.

\begin{tabular}{|l|c|c|}
\hline \multicolumn{1}{|c|}{ Treatments } & $\begin{array}{c}\text { Length of } \\
\text { roots }(\mathrm{mm})\end{array}$ & $\begin{array}{c}\text { Fresh } \\
\text { weight }(\mathrm{g})\end{array}$ \\
\hline Control not inoculated & $114.5 \mathrm{~b}$ & $2.4 \mathrm{~b}$ \\
\hline Control, inoculation F.ox.t. & $77.0 \mathrm{a}$ & $1.2 \mathrm{a}$ \\
\hline $\begin{array}{l}\text { BABA } 100 \mu \mathrm{g} \cdot \mathrm{cm}^{3}, \\
\text { inoculation F.ox.t. }\end{array}$ & $108.5 \mathrm{~b}$ & $1.9 \mathrm{~b}$ \\
\hline $\begin{array}{l}\text { BABA } 250 \mu \mathrm{g} \cdot \mathrm{cm}^{3} \text {,inoculation } \\
\text { F.ox.t. }\end{array}$ & $100.5 \mathrm{~b}$ & $2.2 \mathrm{~b}$ \\
\hline
\end{tabular}

Means in columns followed by the same letter do not differ significantly (5\%) according to Duncan's test.

Table 2

The effect of D,L $\beta$ aminobutyric acid (BABA) on the growth of the root system in cooled tulip bulbs inoculated with spores of Fusarium oxysporum f.sp. tulipae; observation 29 days after inoculation with F.ox.t. 218.

\begin{tabular}{|l|c|c|}
\hline \multicolumn{1}{|c|}{ Treatments } & $\begin{array}{c}\text { Length of } \\
\text { roots }(\mathrm{mm})\end{array}$ & $\begin{array}{c}\text { Fresh } \\
\text { weight }(\mathrm{g})\end{array}$ \\
\hline Control not inoculated & $82.6 \mathrm{~b}$ & $4.3 \mathrm{~b}$ \\
\hline Control, inoculation F.ox.t. & $61.5 \mathrm{a}$ & $1.6 \mathrm{a}$ \\
\hline $\begin{array}{l}\text { BABA } 300 \mu \mathrm{g} \cdot \mathrm{cm}^{3} \text {, inoculation } \\
\text { F.ox.t. }\end{array}$ & $84.5 \mathrm{~b}$ & $3.1 \mathrm{~b}$ \\
\hline
\end{tabular}

Explanation: see Table 1. 


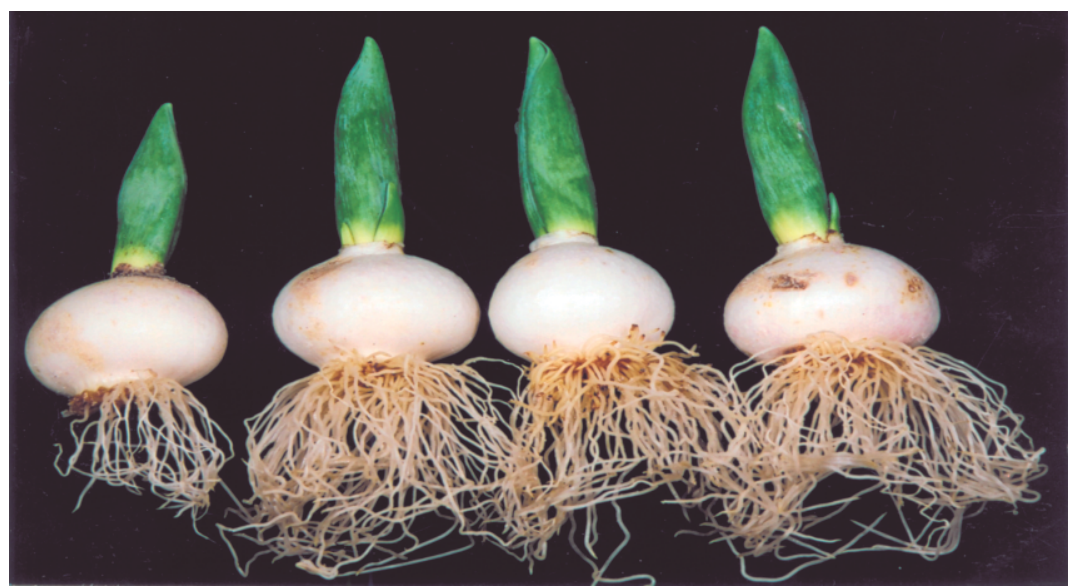

Fig. 1. The effect of D,L $\beta$ aminobutyric acid (BABA) on the growth of the root system in uncooled tulip bulbs inoculated with spores of Fusarium oxysporum f. sp, tulipae (F.ox.t. 218)

from left: control inoculated with F.ox.t.; control not inoculated; BABA $100 \mu \mathrm{g}^{\cdot} \mathrm{cm}^{3}$ and inoculated with F.ox.t.; BABA $250 \mu \mathrm{g} \cdot \mathrm{cm}^{3}$ and inoculated with F.ox.t.

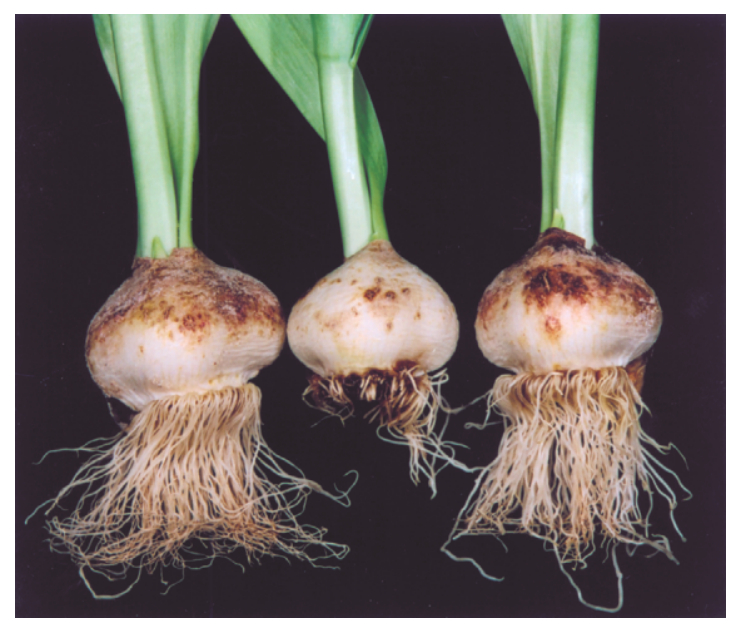

Fig. 2. The effect of D,L $\beta$ aminobutyric acid (BABA) on the growth of the root system in cooled tulip bulbs inoculated with spores of Fusarium oxysporum f. sp. tulipae (F.ox.t. 218)

on left control not inoculated,

middle control inoculated with F.ox.t.,

on right $\mathrm{BABA} 300 \mu \mathrm{g} \cdot \mathrm{cm}^{3}$ and inoculated with F.ox.t

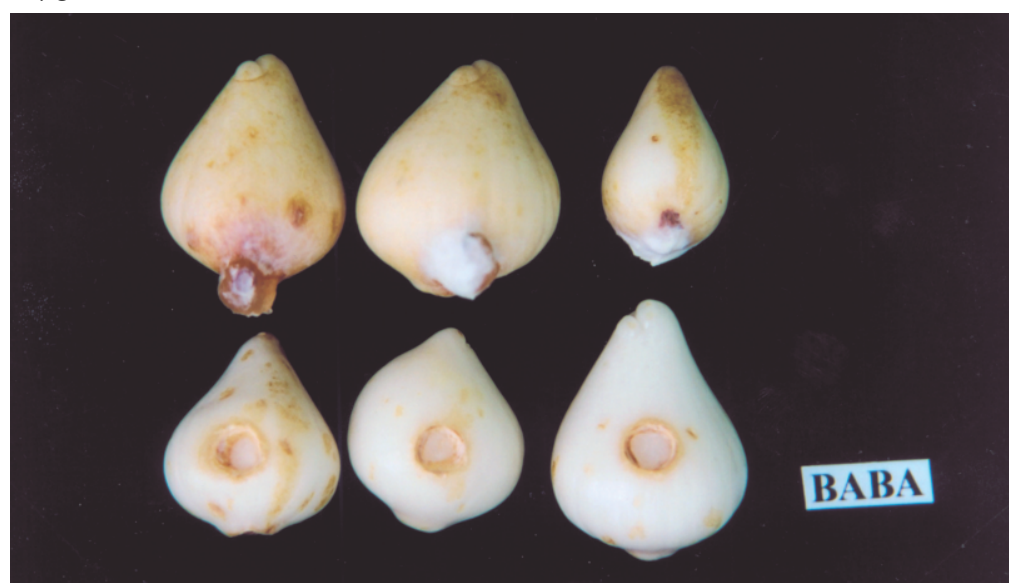

Fig. 3. The effect of D,L $\beta$ aminobutyric acid (BABA) on the development of Fusarium oxysporum f. sp, tulipae (F.ox.t. 218) on tulip bulbs

upper bulbs inoculated with F.ox.t.

lower bulbs soaked preventively in BABA at a concentration of $200 \mu \mathrm{g} \cdot \mathrm{cm}^{3}$ and inoculated with F.ox.t. 


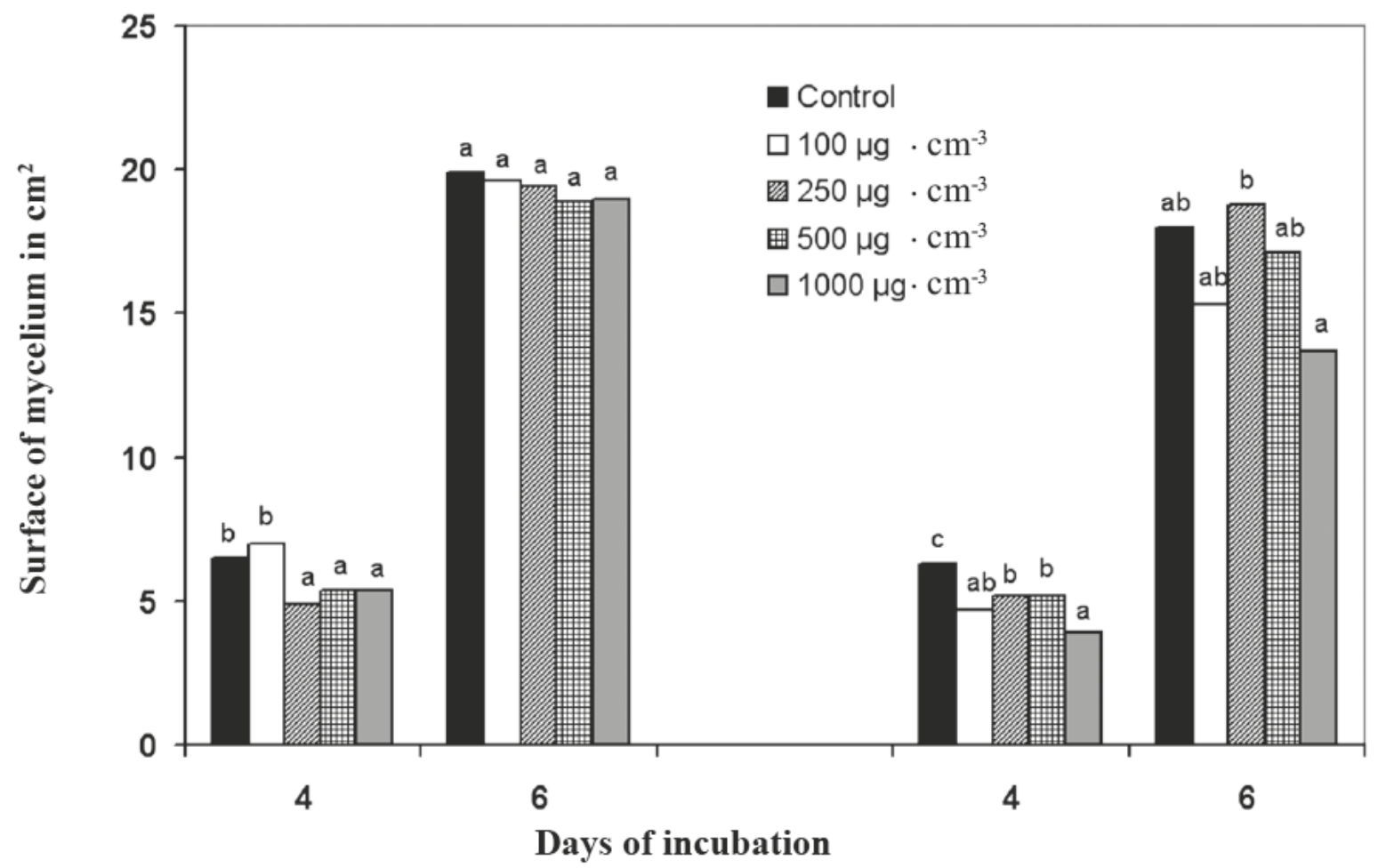

Fig. 4. The effect of D,L $\beta$ aminobutyric acid (BABA) on the growth and development of two isolates of Fusarium oxysporum f. sp. tulipae Fox.t. 17 and F.ox.t. 218 on PDA medium in vitro.

Table 3

The effect of D,L $\beta$ aminobutyric acid (BABA) and Sportak Alpha 380 EC preventively applied for soaking of tulip bulbs on the development of Fusarium oxysporum f. sp. tulipae, observation 8 days after inoculation with F.ox.t. 218.

\begin{tabular}{|l|c|c|c|}
\hline \multicolumn{1}{|c|}{ Treatments } & $\begin{array}{c}\text { Length of } \\
\text { necrosis }\end{array}$ & $\begin{array}{c}\text { Depth of } \\
\text { necrosis }\end{array}$ & Gummosis \\
\hline $\begin{array}{l}\text { Control, inoculation } \\
\text { F.ox.t. }\end{array}$ & $11.4 \mathrm{c}$ & $2.7 \mathrm{c}$ & strong \\
\hline $\begin{array}{l}\text { BABA } 100 \mu \mathrm{g} \cdot \mathrm{cm}^{3}, \\
\text { inoculation F.ox.t. }\end{array}$ & $6.1 \mathrm{~b}$ & $0.9 \mathrm{~b}$ & lack \\
\hline $\begin{array}{l}\text { BABA } 200 \mu \mathrm{g} \cdot \mathrm{cm}^{3}, \\
\text { inoculation F.ox.t. }\end{array}$ & $0.0 \mathrm{a}$ & $0.0 \mathrm{a}$ & lack \\
\hline $\begin{array}{l}\text { Sportak Alpha } \\
\text { 380 EC } 400 \mu \mathrm{g} \cdot \mathrm{cm}^{3}, \\
\text { inoculation F.ox.t. }\end{array}$ & $0.0 \mathrm{a}$ & $0.0 \mathrm{a}$ & lack \\
\hline
\end{tabular}

Explanation: see Table 1.

und to be similar to that of the control bulbs not inoculated with F.ox.t. 218 (Tab. 1, 2; Figs. 1, 2).

On PDA medium, colonies of the pathogen mycelium were growing from the fragments of browned roots and dark spots on the basal plate of the bulb from the control inoculated with F.ox.t. 218, as well as from the root fragments and the basal plate without visible changes in their colour of the bulbs soaked in BABA before the inoculation with spores of F.ox.t. 218. But no colonies of F.ox.t. 218 were found growing from the roots and the basal plate of the control bulbs not inoculated with F.ox.t. 218. The presence of the pathogen in the tissue of the roots and basal plate of the bulbs preventively soaked in BABA and inoculated with F.ox.t. 218 , in the absence of the symptom of browning and rot of the roots and basal plate, indicates the $\mathrm{D}, \mathrm{L}-\beta$-aminobutyric acid-induced protective response of the plant.

Preventively applied BABA for soaking tulip bulbs for 12 hours had an inhibitory effect on the development of fusariosis. At a concentration of $100 \mu \mathrm{g} \cdot \mathrm{cm}^{-3}$, BABA limited in about $50 \%$ the development of fusariosis on the scales (measured by the size of rot spots on the bulb scales). At a higher concentration applied $\left(200 \mu \mathrm{g} \cdot \mathrm{cm}^{-3}\right)$, BABA, likewise the standard fungicide Sportak Alpha 380 EC (prochloraz + carbendazim), completely inhibited the development of the disease in the tissue of the tulip bulb scale. It should be added that in the place of inoculation with spores of F.ox.t. 218, in the bulbs preventively soaked in BABA, the germination of spores and developing hyphae of the mycelium were observed, but no penetration of the pathogen in the scale tissue was found (Tab. 3; Fig. 3).

On the control bulbs inoculated with F.ox.t. 218, the development of the mycelium, the formation of rot 
spots and gum secretion were observed (Tab. 3; Fig. 3). In the bulbs preventively treated with BABA and the fungicide Sportak Alpha 380 EC, no gum secretion was observed; it should be thought that the inhibition of the development of fusariosis on the scales by these preparations resulted in a reduced production of ethylene by Fot, insufficient for gum induction.

At concentrations of $100-1000 \mu \mathrm{g}^{\cdot} \mathrm{cm}^{-3}$, BABA did not inhibit the growth of the mycelium of F.ox.t. 17 and inhibited to a very small extent the growth of the mycelium of F.ox.t. 218 isolate on potato dextrose agar medium (PDA-Merck). It proves that the BABAinduced protective mechanism in tulip roots and bulbs is related to resistance induction and not the direct influence on the pathogen (Fig. 4).

Li et al. (1996) found that BABA induced resistance of cotton plants against Verticillium dahliae and tomato plants against Fusarium oxysporum f. sp. lycopersici, but it did not affect the growth of the mycelium of these pathogens under in vitro conditions. BABAalso induced systematic resistance of lettuce against downy mildew (Bremia lactucae Regel), but even at high concentrations ( $20 \mathrm{mM})$ it did not inhibit the germination of spores, what proves not direct influence on the pathogen (Pajot et al. 2001). Hamiduzzaman et al. (2005) showed that BABA induced resistance of grapevine against downy mildew [Plasmopara viticola (Berk. et Curt) Berl. et de Toni] through the sensitization of plants to callose formation and the potentiation of jasmonic acid signalling.

It is believed that BABA does not take part in the resistance response induction mechanisms, but it sensitizes the basic, wide spectrum of known resistance response mechanisms partially associated with systemic acquired resistance (SAR), the effect of abscisic acid (ABA), and even induced systemic resistance (ISR), i.e. it causes a faster and stronger activation of protective mechanisms to abiotic and biotic stresses (Ton et al. 2005).

\section{CONCLUSIONS}

1. Preventively applied D,L- $\beta$-aminobutyric acid (BABA) inhibited the development of fusariosis on tulip bulbs and roots.

2. BABA does not inhibit the growth of the mycelium of $F$. oxysporum $\mathrm{f}$. sp. tulipae in vitro on PDA medium; it proves that BABA does not affect directly the pathogen, but it induces resistance in tulip roots and bulbs, limiting the development of fusariosis.

\section{REFERENCES}

Chamsai J., Siegrist J., Buchenauer H., 2004. Mode of action of the resistance inducing 3 aminobutyric acid in tomato roots against Fusarium wilt. Journal of Plant Diseases and Protective 111: 273291.
Cohen Y., 2002. $\beta$ Aminobutyric acid induced resistance aga inst plant pathogens. Plant Disease 86: 448457.

Hamiduzzaman M. Md., Jakab B., Barnavon L., Neuhaus J. M., Mauch Mani B., 2005. $\beta$ Amino butyric acid induced resistance against downy mildew in grapevine acts through the potentiation of callose for mation and jasmonic acid signaling. Mol. Plant Microbe Interact. 18: 819829 .

Jakab G., Cottier V., Topquin V., Rigoli G., Zim merli I., Metraux J. P., Mauch Mani B., 2001. $\beta$ Aminobutyric acid induced resistance in plants. Eur. J. Plant Pathol. 107: 2937.

Li J., Zingen Sell I., Buchenauer H., 1996. Induction of resistance of cotton plants to Verticillium wilt and of tomato plants to Fusarium wilt by 3 aminobutyric acid and methyl jasmonate. Journal of Plant Diseases and Pro tective, 103: 288299

Pajot E., Le Corre D., Siluè A., 2001. Phytogard ${ }^{\circledR}$ and DL $\beta$ amino butyric acid (BABA) induced resistance to do wny mildew (Bremia lactucae) in lettuce (Lactuca sativa L). Eur. J. Plant Pathol. 107: 861869.

Reuveni M., Zahavi T., Cohen Y., 2001. Controlling do wny mildew (Plasmopara viticola) in field grown gra pevine with $\beta$ aminobutyric acid (BABA). Phytopara sitica, 29: 29

Ton J., Jacob G., Toquin V., Flors V., Iavicoli A., Maeder M. N., Métraux J. P., Mauch Mani B., 2005. Dissecting the $\beta$ aminobutyric acid induced pri ming phenomenon in Arabidopsis. Plant Cell, 17: 987 999.

Wplyw kwasu D,L- $\beta$-aminomasłowego na wzrost i rozwój Fusarium oxysporum f. sp. tulipae (Apt.)

\section{Streszczenie}

Badano wpływ kwasu D,L- $\beta$-aminomasłowego (BABA) na wzrost i rozwój systemu korzeniowego i rozwój fuzariozy na cebulach tulipana 'Apeldoorn' zainokulowanych Fusarium oxysporum f. sp. tulipae (F.ox.t. 218). W doświadczeniach analizowano: długość i świeżą masę korzeni oraz stopień rozwoju choroby na cebulach tulipana.

U cebul nie przechłodzonych i przechłodzonych traktowanych profilaktycznie BABA w stężeniach 100, 250 i $300 \mu \mathrm{g} \cdot \mathrm{cm}^{-3}$, a następnie inokulowanych F.ox.t. 218 stwierdzono podobny rozwój systemu korzeniowego jak u cebul kontrolnych nie inokulowanych. Profilaktycznie zastosowany BABA w stężeniu $100 \mu \mathrm{g} \cdot \mathrm{cm}^{-3}$ do moczenia cebul tulipana ograniczył o $50 \%$ rozwój fuzariozy na łuskach, a w stężeniu $200 \mu \mathrm{g} \cdot \mathrm{cm}^{-3}$ całkowicie zahamował rozwój choroby. BABA w stężeniach $100-1000 \mu \mathrm{g} \cdot \mathrm{cm}^{-3}$ nie hamował wzrostu grzybni badanych izolatów F.ox.t. 17 i F.ox.t. 218 na pożywce agarowo-ziemniaczano-glukozowej. 
